\title{
Chemical Conditioning as an Approach to Ischemic Stroke Tolerance: Mitochondria as the Target
}

\author{
Zhen Jin, Jinzi Wu and Liang-Jun Yan * \\ Department of Pharmaceutical Sciences, UNT System College of Pharmacy, University of North Texas Health \\ Science Center, Fort Worth, TX 76107, USA; zhen.jin@unthsc.edu (Z.J.); jinzi.wu@unthsc.edu (J.W.) \\ * Correspondence: liang-jun.yan@unthsc.edu; Tel.: +1-817-735-2386; Fax: +1-817-735-2603 \\ Academic Editor: Cesar Borlongan \\ Received: 11 February 2016; Accepted: 4 March 2016; Published: 8 March 2016
}

\begin{abstract}
It is well established that the brain can be prepared to resist or tolerate ischemic stroke injury, and mitochondrion is a major target for this tolerance. The preparation of ischemic stroke tolerance can be achieved by three major approaches: ischemic conditioning, hypoxic conditioning and chemical conditioning. In each conditioning approach, there are often two strategies that can be used to achieve the conditioning effects, namely preconditioning (Pre-C) and postconditioning (Post-C). In this review, we focus on chemical conditioning of mitochondrial proteins as targets for neuroprotection against ischemic stroke injury. Mitochondrial targets covered include complexes I, II, IV, the ATP-sensitive potassium channel (mitoKATP), adenine dinucleotide translocase (ANT) and the mitochondrial permeability transition pore (mPTP). While numerous mitochondrial proteins have not been evaluated in the context of chemical conditioning and ischemic stroke tolerance, the paradigms and approaches reviewed in this article should provide general guidelines on testing those mitochondrial components that have not been investigated. A deep understanding of mitochondria as the target of chemical conditioning for ischemic stroke tolerance should provide valuable insights into strategies for fighting ischemic stroke, a leading cause of death in the world.
\end{abstract}

Keywords: chemical conditioning; ischemic conditioning; hypoxic conditioning; mitochondria; neuroprotection; stroke injury

\section{Introduction}

The brain is a vulnerable target of ischemic stroke injury, but can also be made to resist or tolerate such an injury [1-5]. Brain ischemic tolerance can be achieved by a variety of approaches [6-8], of which the most extensively-studied ones are conditioning that encompasses preconditioning (Pre-C) and postconditioning (Post-C) [9-12]. Under the concept of conditioning, further categories can be classified depending on the design of conditioning induction. When conditioning is achieved by short cycles of ischemic reperfusion, the strategy is known as ischemic conditioning $[13,14]$. When conditioning is achieved by one cycle or many short cycles of hypoxic exposure, the strategy is known as hypoxic conditioning [15]. If the conditioning is achieved by chemicals or pharmacological drugs that usually target proteins, such an approach is often called chemical hypoxia or chemical conditioning [16]. It should be noted that both hypoxic conditioning and chemical conditioning are cross-tolerance approaches [17], as the induction of ischemic tolerance is not achieved via ischemia. Importantly, regardless of which category of conditioning, both Pre-C and Post-C strategies under a given conditioning approach involve triggering the endogenous neuroprotective responses during the conditioning phases that can be in full-fledged action upon subsequent severe ischemic injury [11,18-20]. Mitochondria are known to be involved in ischemic stroke injury and chemical-induced ischemic tolerance [21-24]. Therefore, in this review, we first discuss the role of mitochondria in ischemic injury, ischemic conditioning and hypoxic conditioning and then focus on 
mitochondrial protein targets that have been widely studied in the context of chemical conditioning and neuroprotection in ischemic stroke injury.

\section{Mitochondria and Ischemic-Reperfusion Injury}

Mitochondria are known to play a major role in ischemic/reperfusion injury [25-27]. During ischemia, ATP production by mitochondria is dramatically deceased due to the lack of nutrients and oxygen [28]. This decrease in ATP levels leads to impairment in ATP-dependent $\mathrm{Ca}^{2+}$ channels, resulting in accumulation or overload of cellular and mitochondrial $\mathrm{Ca}^{2+}$ [28]. In the meantime, lack of blood flow also causes accumulation of lactate, as cells are forced to undergo anaerobic respiration [28]. Consequently, cellular $\mathrm{pH}$ decreases, which induces the closure of the mitochondrial membrane permeability transition pore [28]. Upon reperfusion, a sudden resupply of oxygen and nutrients re-energizes mitochondrial aerobic respiration, resulting in a further load of mitochondrial $\mathrm{Ca}^{2+}$, mitochondrial permeability transition pore ( $\mathrm{mPTP}$ ) opening and a burst in reactive oxygen species (ROS) production [29-31]. Cytochrome c release due to MPTP opening would set off the cellular apoptotic process [32,33], and ROS generation would cause widespread oxidative damage to macromolecules, such as DNA, lipids and proteins [34-39]. The occurrence of these events converging on mitochondria would eventually lead to cell death and tissue infarction [40]. Therefore, mitochondria have been investigated as a major target for neuroprotection in ischemic brain injury [20,41-43].

\section{Ischemic Conditioning: Ischemic Pre-C and Post-C}

In ischemic Pre-C, the brain is subjected to short episodes of ischemic reperfusion followed by a severe ischemic stroke attack [44-46] (Figure 1A). In ischemic Post-C, the reperfusion process following a period of ischemia is interrupted by several short cycles of ischemia [11,12,47] (Figure 1B). This approach, though developed much later than that of ischemic Pre-C, has gained great attention and momentum in the field of stroke research. The reason is that stroke is really an unpredictable mishap, so Post-C is more clinically relevant than Pre-C. Nonetheless, Pre-C still remains an intensively-studied area because it can be manipulated to understand the endogenous neuroprotective mechanisms [48-50]. It should be noted that the cycle number for the short episodes of ischemic reperfusion conducted before or after lethal ischemic stroke injury can vary considerably depending on the purpose of a study.

\section{Ischemic conditioning}

A: Ischemic preconditioning

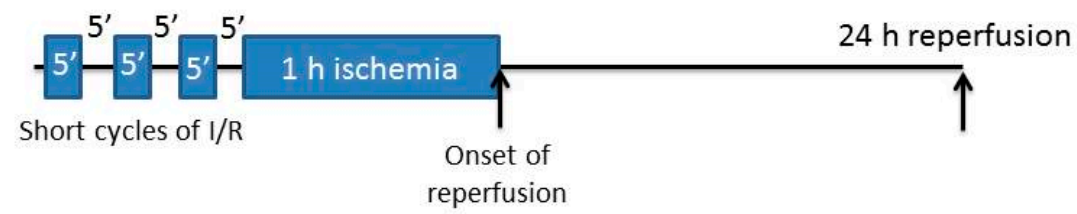

B: Ischemic postconditioning:

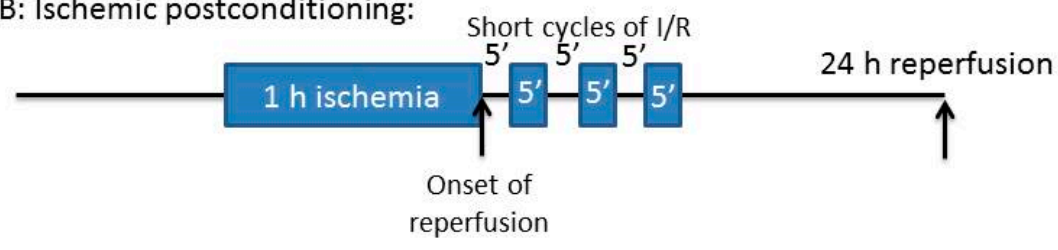

Figure 1. General scheme of ischemic preconditioning and ischemic postconditioning. The short cycles of ischemia reperfusion can be used either preconditioning induction (A) or postconditioning induction (B). As there are no standard procedures for ischemic conditioning, the number of cycles varies widely from investigator to investigator. 


\section{Hypoxic Conditioning: Hypoxic Pre-C and Post-C}

Similar to ischemic Pre-C and Post-C, hypoxic Pre-C and Post- $\mathrm{C}$ have also been widely used as neuroprotective approaches [51,52]. Shown in Figure 2 are the general approaches of hypoxic exposure conducted either before or after lethal ischemic stroke. As there are no standard procedures for hypoxic exposure, the schemes in Figure 2 only show representative procedures that can vary from investigator to investigator. Under many conditions, repetitive hypoxic exposure, whether Pre- $\mathrm{C}$ or Post- $\mathrm{C}$, is performed [53].

\section{Hypoxic conditioning}

A: Hypoxic preconditioning
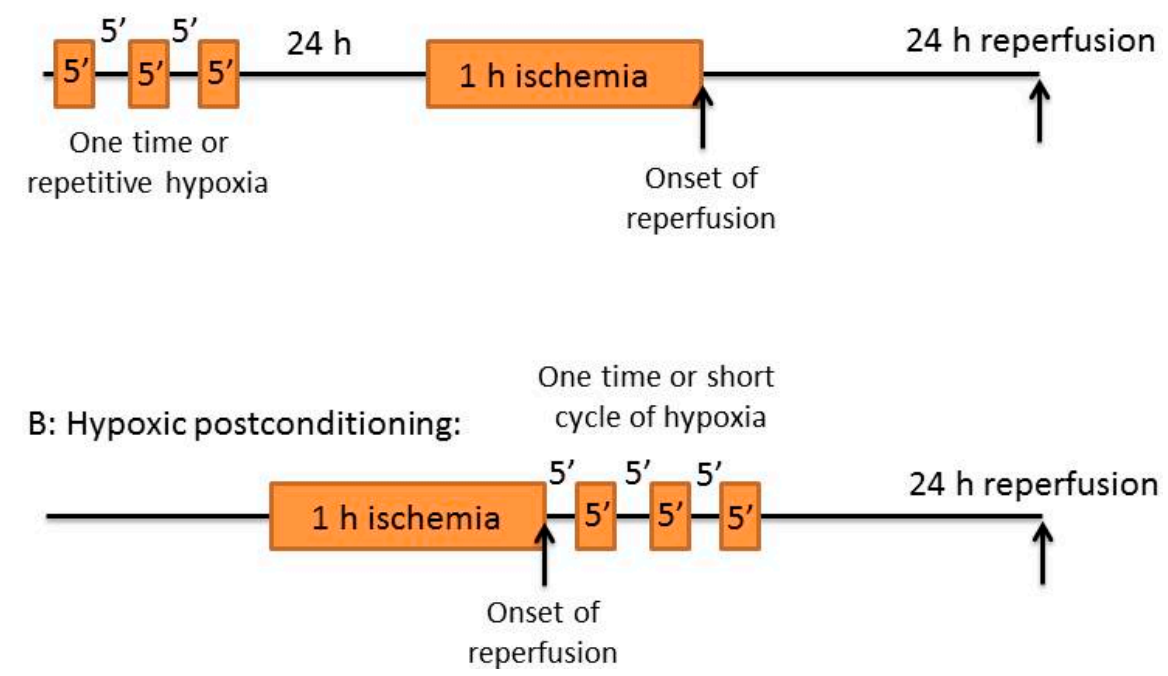

Figure 2. Representative scheme of hypoxic preconditioning and postconditioning. Similar to that of ischemic conditioning, the short cycles of hypoxia exposure can be applied either before (A) or after (B) lethal stroke. There are also no standard procedures for hypoxic conditioning, so the protocol could change significantly from laboratory to laboratory.

\section{Chemical Conditioning: Chemical Pre-C and Post-C}

It has long been known that chemicals or pharmacological agents can be used to make the brain resistant to ischemic stroke injury [54-56]. The process of chemically-induced ischemic stroke tolerance is a cross tolerance [57], as the induction of conditioning is not achieved by ischemia, but by chemicals or pharmacological agents. Chemically-induced ischemic tolerance is also often called chemical hypoxia [58,59]. This is because the use of chemicals at a sublethal dosage always impacts cellular mitochondrial respiration, whereby cells work under hypoxic conditions. The conditioning process can stress cells, but does not impair cellular function or lead to cell death, thereby preparing cells to prevent from further lethal ischemic stroke injury. General approaches of chemical conditioning, including both Pre-C and Post- $\mathrm{C}$, are shown in Figure 3. In Pre-C settings, a chemical is administered before ischemic stroke so that a preventive purpose could be served. In Post- $C$ settings, a chemical is administered at the onset of reperfusion, whereby the reperfusion process is disrupted or interfered with, so that less tissue damage could be achieved. If the induction agent is administered after reperfusion has started, say a few hours after the onset of reperfusion, such an approach would be known as delayed chemical conditioning [60]. We think chemical conditioning is more feasible than ischemic or hypoxic conditioning because a given chemical can be readily administered via injection or inhalation without needing any other equipment or instruments. 


\section{Chemical conditioning}

A: Chemical preconditioning

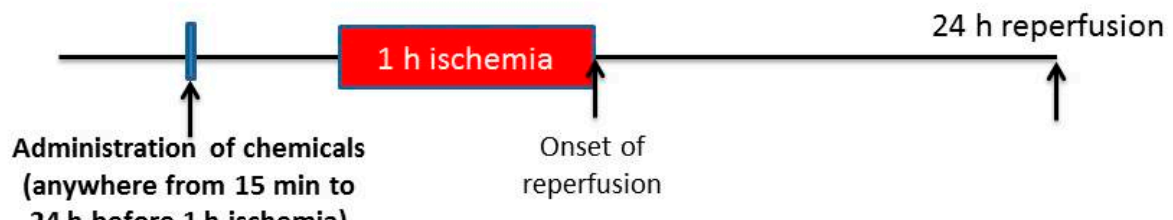

(anywhere from $15 \mathrm{~min}$ to

reperfusion

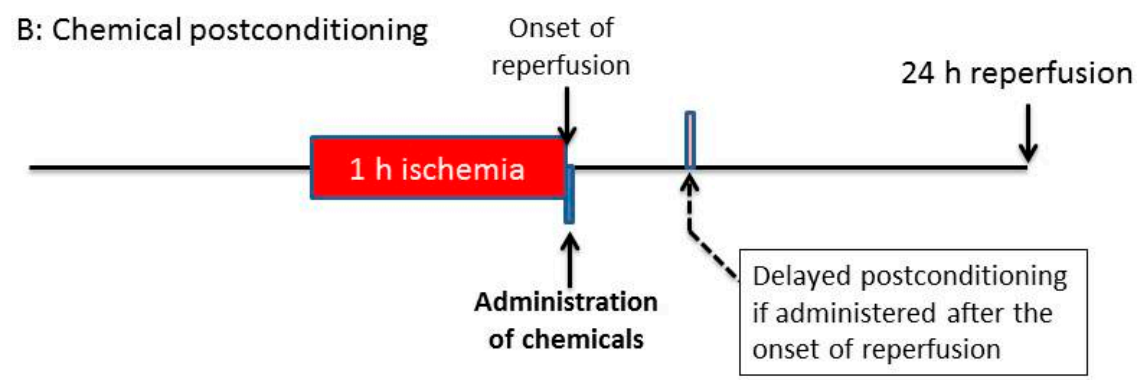

Figure 3. Representative scheme of chemical conditioning. The administration of the chemical agent or pharmacological drugs can be given either before (A) or after (B) lethal ischemic stroke. If the chemical is given during the reperfusion process instead of at the onset of reperfusion, delayed postconditioning effects would be induced.

\section{Components of Mitochondrial Metabolic Pathways as Targets of Chemical Conditioning}

In ischemic conditioning and hypoxic conditioning, there is often no specific target that could be defined. In contrast, when chemical conditioning is conducted, the target is often known because the chemical or compound is used to either inhibit or activate the function of a protein. When it comes to mitochondria as the target for chemical conditioning, literally, any proteins in mitochondria can serve as chemical conditioning targets as long as an inhibitor or activator of such a target exists or can be artificially synthesized. Obviously, the components of the mitochondrial metabolic pathways are ideal targets due to their involvement in oxygen consumption and nutrient electron extraction, as well as electron storage in nicotinamide adenine dinucleotide (NADH) and flavin adenine dinucleotide $\left(\mathrm{FADH}_{2}\right)$ [61,62]. As shown in Figure 4, the mitochondrial metabolic pathways mainly involve the breakdown of pyruvate to form acetyl-CoA by pyruvate dehydrogenase, beta oxidation of fatty acids to also yield acetyl-CoA, amino acid residues' catabolism to generate acetyl-CoA or the intermediates in the Krebs cycle and complete combustion of acetyl-CoA to carbon dioxide in the Krebs cycle. This is followed by electron transport from either $\mathrm{NADH}$ at complex I or $\mathrm{FADH}_{2}$ at complex II to oxygen via coenzyme $Q$ and cytochrome $c$ and, finally, ATP production at complex V $[61,63]$. All of the enzymes involved in these metabolic pathways could be potential targets of chemical hypoxia or chemical Pre-C or Post-C. Surprisingly, many of the enzymes involved in these metabolic pathways have not been investigated in the context of chemical conditioning and neuroprotection against ischemic stroke injury. However, the importance of these enzymes as possible chemical conditioning targets should not be discounted just because they have not been studied. The major mitochondrial components that have been studied as chemical conditioning targets and that are covered in this review are shown in Figure 5. These include complexes I, II, IV, the ATP-sensitive $\mathrm{K}^{+}$channel (mitoKATP), adenine dinucleotide translocase (ANT) and the mitochondrial permeability transition pore (mPTP). In the following sections, we will summarize reported studies involving chemical conditioning of these mitochondrial components as stroke tolerance targets. As our purpose is by no means to exhaust the literature, we focus on the major mitochondrial targets that have been widely studied. Hence, we 
apologize to those whose work is not cited in this review. It should be noted that we have not found ample reports in the literature (mainly via PubMed searches) about chemical conditioning targeting complexes III and V for stroke tolerance.

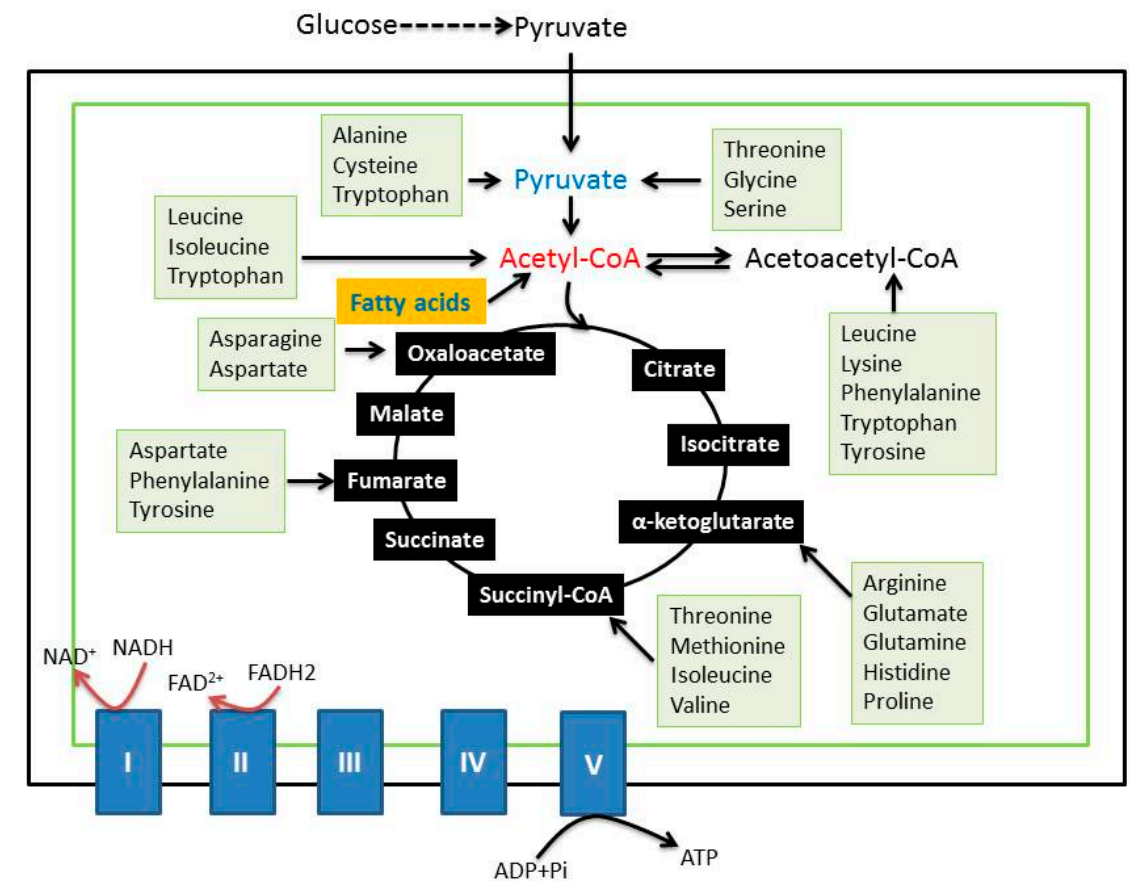

Figure 4. Overview of mitochondrial metabolic pathways that could be potential targets for chemical conditioning for neuroprotection against ischemic stroke injury. These pathways mainly include glucose metabolism, fatty acid oxidation, amino acid breakdown, the Krebs cycle and the electron transport chain, as well as oxidative phosphorylation. Numerous enzymes in these pathways have not been explored in terms of chemical conditioning and stroke protection, providing great opportunities for future studies of chemical conditioning and stroke protection.



Figure 5. Mitochondrial targets covered in this review. These targets include complexes I, II and IV, the mitoKATP channel, adenine dinucleotide translocase (ANT) and the mitochondrial permeability transition pore comprised of ANT, the voltage-dependent anion channel (VDAC) and cyclophilin D. Please see the text for details. 


\subsection{Complex I Inhibition by Isoflurane}

Isoflurane has been found to elicit both Pre-C and Post-C effects in many organs [64]. It is known to inhibit mitochondrial complex I [65-69], a major site for ROS generation [70-73]. In a Post-C study, Sosunov et al. [69] have found that isoflurane given upon reperfusion attenuated mitochondrial ROS production by inhibiting complex I function and the recovery of mitochondrial oxidative phosphorylation. The underlying mechanism involves a decreased hydrogen peroxide production, hence an attenuated oxidative stress in the brain and a decreased infarction volume. In contrast to the complex II and ANT preconditioning studies discussed below, this study indicates no positive roles of ROS, as ROS release from complex I was shown to be the main culprit of oxidative damage in the brain. As the study used neonatal mice as its animal model, whether the age of the mice could contribute to the deleterious role of ROS in neonatal mice remains unknown. Using adult rabbits, however, Ludwig et al. [74] have reported that isoflurane-mediated preconditioning in the brain involves ROS production at the site of complex III. It should be noted that isoflurane may also indirectly target other mitochondrial proteins or pathways [75]. For example, isoflurane Post-C may involve its inhibition of the mitochondrial permeability transition pore in neonatal rat brain [76]. It should also be noted that rotenone [77,78], a widely-used complex I inhibitor, has not been tested in the context of chemical conditioning and brain stroke tolerance, which is probably due to its toxicity $[79,80]$. The same is also true for antimycin A, a well-known complex III inhibitor [81,82].

\subsection{Inhibition of Succinate Dehydrogenase (Complex II) by 3-Nitropropionate}

3-Nitropropionate (3-NPA) is a well-known inhibitor of complex II that is the only complex sitting in both the Krebs cycle and the electron transport chain [83]. 3-NPA is an irreversible complex II inhibitor [84] and has been well studied in Pre-C-induced neuroprotection, as well as cardioprotection [85,86]. A series of studies conducted by Dirnagl and his colleagues have demonstrated that 3-NPA inhibition of complex II inhibits mitochondrial oxidative phosphorylation and increases hypoxic tolerance, both in animal studies and in cell culture studies $[54,56]$. Importantly, the 3-NPA regimen used in their studies did not induce any detectable cell death or behavioral changes. The mechanisms of 3-NPA-induced ischemic tolerance are believed to involve ROS production, as the antioxidant dimethylthiourea, when administered before 3-NPA treatment, abolished 3-NPA's neuroprotective effect [87], indicating that ROS are required for 3-NPA-induced preconditioning and neuroprotection.

\subsection{Preconditioning of Cytochrome c Oxidase (Complex IV) by Cyanide}

Cyanide is a well-known inhibitor of cytochrome c oxidase [88], so-called complex IV, that is the last component of the electron transport chain [89]. It has been reported that inhibition of complex IV by a sublethal dosage of sodium cyanide can prevent neurotoxicity by a lethal dosage of sodium cyanide [90]. This cyanide-induced preconditioning against cyanide-induced neurotoxicity is not cross tolerant and was manifested by the maintenance of mitochondrial membrane potential and increased levels of Bcl-2 and Bcl-XL, indicating preservation of mitochondrial function [90]. It should be noted that the authors did not explore whether cyanide-induced preconditioning has any protective effect against ischemic stroke injury that would be a cross tolerance study.

\subsection{Inhibition of Adenine Nucleotide Translocase by Carbon Monoxide}

Queiroga et al. [91] found that CO can elicit a protective response against astrocyte cell death induced by diamide, a thiol crosslinking agent that usually causes oxidative stress [92]. The authors found that $\mathrm{CO}$ works by directly enhancing ANT function via a mechanism of protein s-glutathionylation. As ANT is part of the mitochondrial permeability transition pore (mPTP) [93,94], the functional enhancement of ANT actually prevents ANT's pore forming function, leading to no mitochondrial membrane swelling and no cytochrome c release. Additionally, CO preconditioning 
also involves ROS formation, as the use of $\beta$-carotene can abolish CO's protective action. This study further confirms that ROS formation during preconditioning is essential for a preconditioning effect.

\subsection{Inhibition of Mitochondrial Permeability Transition Pore by Carbon Dioxide}

In an elegant study, Fan et al. [95] have found that carbon dioxide $\left(\mathrm{CO}_{2}\right)$ also can elicit a Post-C neuroprotective effect. The authors found that stroked mice receiving varying dosages of $\mathrm{CO}_{2}$ at 5,50 or $100 \mathrm{~min}$ after onset of reperfusion showed a pronounced neuroprotective effect after ischemic stroke injury. The protective effect of $\mathrm{CO}_{2}$ was found to be due to its induction of mild acidosis, as $\mathrm{NaHCO}_{3}$, an agent that can elevate $\mathrm{pH}$, greatly compromised the neuroprotective effect of $\mathrm{CO}_{2}$. The authors found that $\mathrm{CO}_{2}$-induced acidosis inhibits MPTP and cytochrome c release, which can be abolished by the mPTP opener atractyloside, further demonstrating that $\mathrm{CO}_{2}$-induced Post- $\mathrm{C}$ is due to its acidic inhibition of MPTP.

\subsection{Activation of the Mitochondrial ATP-Sensitive $\mathrm{K}^{+}$Channel by Diazoxide}

The mitochondrial ATP-sensitive $\mathrm{K}^{+}$channel (mitoKATP) is a well-studied target for ischemic stroke tolerance and neuroprotection [96-99]. The neuroprotective effects of mitoATP in both Pre-C and Post- $\mathrm{C}$ have been evaluated. In Pre-C studies, diazoxide as the channel's opener has been widely used [100]. Wu et al. [101] have reported that activation of mitoKATP by diazoxide $20 \mathrm{~min}$ before ischemia significantly improved neurological scores with a concurrent decrease in infarction volume. This protective effect could also be induced by cyclosporine A, which is an inhibitor of mPTP, demonstrating that mPTP closure following mitoKATP opening is involved in this protective response. Accordingly, the use of mPTP opener atractyloside diminished the neuroprotective effects of diazoxide and cyclosporine $\mathrm{A}$.

In a Post-C study, Robin et al. [99] have reported that mitoKATP opening by diazoxide right before the start of reperfusion conferred significant neuroprotection. In this study, diazoxide was used in conjunction with ischemic Post-C comprising three episodes of $30 \mathrm{~s}$ of occlusion and reperfusion. The authors found that diazoxide resulted in a $60 \%$ decrease in infarction volume, and this effect was abolished by mitoKATP blocker 5-hydroxydecanoate (5-HD). Additionally, no delayed postconditioning effect was observed, as Post-C applied 5 min after the onset of reperfusion did not yield neuroprotection. However, in tissue culture studies, diazoxide was shown to trigger delayed Pre-C effects [98].

It should be noted that administration of diazoxide alone in the absence of post ischemic interruption of the reperfusion process has also been shown to confer neuroprotection [102]. Additionally, in addition to MPTP, ROS and calcium have been established as the mediators in diazoxide-induced neuroprotection [43].

\subsection{Mitochondrial Biogenesis and Ischemic Tolerance}

While numerous studies have focused on one protein target or one signaling pathway, mitochondrial biogenesis as a whole has also been investigated in the process of ischemic tolerance induced by chemical conditioning. For example, Stetler et al. [103] have reported that upon lipopolysaccharide (LPS)-induced preconditioning, mitochondrial biogenesis was observed, and this biogenesis is linked to ischemic tolerance. Many makers of mitochondrial biogenesis were found to be elevated by LPS, whose stroke tolerance effects have been well studied [104-107]. These markers include mitochondrial DNA copy number and mitochondrial transcription factor A (TFAM). The observation of mitochondrial biogenesis was further supported by TFAM knockdown, which attenuated mitochondrial biogenesis and ischemic tolerance induced by LPS preconditioning. This study demonstrates that mitochondrion, as an organelle, contributes to chemical-induced ischemic tolerance in the brain. 


\section{Summary and Future Perspectives}

In this review, we have summarized evidence that chemical-induced ischemic stroke tolerance can be achieved by targeting mitochondrial proteins. We discussed a variety of targets, including complexes I, II, IV, ANT, mPTP and mitoKATP. Chemical agents that are covered in this review include $\mathrm{CO}$, 3-NPA, $\mathrm{CO}_{2}$, isoflurane, diazoxide and cyanide. As some of these agents or their targets have not been tested in both Pre-C and Post-C settings, it would be interesting to evaluate their comprehensive effects on ischemic stroke tolerance in the future. Moreover, many mitochondrial proteins have not been explored as chemical conditioning targets for stroke tolerance, which should also be explored in the future. We believe that studies on elucidating the mechanisms of chemical-induced tolerance against stroke injury involving mitochondria as the target could eventually help fighting ischemic stroke, which is a leading cause of death globally.

Acknowledgments: Liang-Jun Yan was supported in part by the National Institute of Health (Grant R01NS079792).

Author Contributions: Liang-Jun Yan conceived the idea. Zhen Jin, Jinzi Wu, and Liang-Jun Yan did the literature search and generated together the outline of the review. Liang-Jun Yan wrote the paper.

Conflicts of Interest: The authors declare no conflict of interest.

\section{References}

1. Kitagawa, K.; Matsumoto, M.; Tagaya, M.; Hata, R.; Ueda, H.; Niinobe, M.; Handa, N.; Fukunaga, R.; Kimura, K.; Mikoshiba, K.; et al. "Ischemic tolerance" phenomenon found in the brain. Brain Res. 1990, 528, 21-24. [CrossRef]

2. Della-Morte, D.; Guadagni, F.; Palmirotta, R.; Ferroni, P.; Testa, G.; Cacciatore, F.; Abete, P.; Rengo, F.; Perez-Pinzon, M.A.; Sacco, R.L.; et al. Genetics and genomics of ischemic tolerance: Focus on cardiac and cerebral ischemic preconditioning. Pharmacogenomics 2012, 13, 1741-1757. [CrossRef] [PubMed]

3. Prass, K.; Scharff, A.; Ruscher, K.; Lowl, D.; Muselmann, C.; Victorov, I.; Kapinya, K.; Dirnagl, U.; Meisel, A. Hypoxia-induced stroke tolerance in the mouse is mediated by erythropoietin. Stroke 2003, 34, 1981-1986. [CrossRef] [PubMed]

4. Obrenovitch, T.P. Molecular physiology of preconditioning-induced brain tolerance to ischemia. Physiol. Rev. 2008, 88, 211-247. [CrossRef] [PubMed]

5. Wang, Y.; Reis, C.; Applegate, R., 2nd; Stier, G.; Martin, R.; Zhang, J.H. Ischemic conditioning-induced endogenous brain protection: Applications pre-, per- or post-stroke. Exp. Neurol. 2015, 272, 26-40. [CrossRef] [PubMed]

6. Cuomo, O.; Vinciguerra, A.; Cerullo, P.; Anzilotti, S.; Brancaccio, P.; Bilo, L.; Scorziello, A.; Molinaro, P.; di Renzo, G.; Pignataro, G. Ionic homeostasis in brain conditioning. Front. Neurosci. 2015, 9. [CrossRef] [PubMed]

7. Pan, J.; Li, X.; Peng, Y. Remote ischemic conditioning for acute ischemic stroke: Dawn in the darkness. Rev. Neurosci. 2016. [CrossRef] [PubMed]

8. Yamashita, T.; Abe, K. Recent progress in therapeutic strategy for ischemic stroke. Cell Transplant. 2016. [CrossRef]

9. Fairbanks, S.L.; Brambrink, A.M. Preconditioning and postconditioning for neuroprotection: The most recent evidence. Best Pract. Res. Clin. Anaesthesiol. 2010, 24, 521-534. [CrossRef] [PubMed]

10. Pignataro, G.; Cuomo, O.; Vinciguerra, A.; Sirabella, R.; Esposito, E.; Boscia, F.; di Renzo, G.; Annunziato, L. Ncx as a key player in the neuroprotection exerted by ischemic preconditioning and postconditioning. Adv. Exp. Med. Biol. 2013, 961, 223-240. [PubMed]

11. Pignataro, G.; Scorziello, A.; di Renzo, G.; Annunziato, L. Post-ischemic brain damage: Effect of ischemic preconditioning and postconditioning and identification of potential candidates for stroke therapy. Febs J. 2009, 276, 46-57. [CrossRef] [PubMed]

12. Zhao, H. Ischemic postconditioning as a novel avenue to protect against brain injury after stroke. J. Cereb. Blood Flow Metab. 2009, 29, 873-885. [CrossRef] [PubMed]

13. Yamashita, T.; Deguchi, K.; Sehara, Y.; Lukic-Panin, V.; Zhang, H.; Kamiya, T.; Abe, K. Therapeutic strategy for ischemic stroke. Neurochem. Res. 2009, 34, 707-710. [CrossRef] [PubMed] 
14. Dezfulian, C.; Garrett, M.; Gonzalez, N.R. Clinical application of preconditioning and postconditioning to achieve neuroprotection. Transl. Stroke Res. 2013, 4, 19-24. [CrossRef] [PubMed]

15. Rybnikova, E.; Samoilov, M. Current insights into the molecular mechanisms of hypoxic pre- and postconditioning using hypobaric hypoxia. Front. Neurosci. 2015, 9. [CrossRef] [PubMed]

16. Esposito, E.; Desai, R.; Ji, X.; Lo, E.H. Pharmacologic pre- and postconditioning for stroke: Basic mechanisms and translational opportunity. Brain Circ. 2015, 1, 104-113.

17. Sharma, A.; Goyal, R. Experimental brain ischemic preconditioning: A concept to putative targets. CNS Neurol. Disord. Drug Targets 2015. in press.

18. Hassell, K.J.; Ezzati, M.; Alonso-Alconada, D.; Hausenloy, D.J.; Robertson, N.J. New horizons for newborn brain protection: Enhancing endogenous neuroprotection. Arch. Dis. Child. Fetal Neonatal. Ed. 2015, 100, F541-F552. [CrossRef] [PubMed]

19. Dirnagl, U.; Becker, K.; Meisel, A. Preconditioning and tolerance against cerebral ischaemia: From experimental strategies to clinical use. Lancet Neurol. 2009, 8, 398-412. [CrossRef]

20. Dirnagl, U.; Meisel, A. Endogenous neuroprotection: Mitochondria as gateways to cerebral preconditioning? Neuropharmacology 2008, 55, 334-344. [CrossRef] [PubMed]

21. Davis, D.P.; Patel, P.M. Ischemic preconditioning in the brain. Curr. Opin. Anaesthesiol. 2003, 16, 447-452. [CrossRef] [PubMed]

22. Moro, M.A.; Almeida, A.; Bolanos, J.P.; Lizasoain, I. Mitochondrial respiratory chain and free radical generation in stroke. Free Radic. Biol. Med. 2005, 39, 1291-1304. [CrossRef] [PubMed]

23. Sims, N.R.; Anderson, M.F. Mitochondrial contributions to tissue damage in stroke. Neurochem. Int. 2002, 40, 511-526. [CrossRef]

24. Zhan, R.Z.; Fujihara, H.; Baba, H.; Yamakura, T.; Shimoji, K. Ischemic preconditioning is capable of inducing mitochondrial tolerance in the rat brain. Anesthesiology 2002, 97, 896-901. [CrossRef] [PubMed]

25. Jackson, M.J.; Papa, S.; Bolanos, J.; Bruckdorfer, R.; Carlsen, H.; Elliott, R.M.; Flier, J.; Griffiths, H.R.; Heales, S.; Holst, B.; et al. Antioxidants, reactive oxygen and nitrogen species, gene induction and mitochondrial function. Mol. Asp. Med. 2002, 23, 209-285. [CrossRef]

26. Warner, D.S.; Sheng, H.; Batinic-Haberle, I. Oxidants, antioxidants and the ischemic brain. J. Exp. Biol. 2004, 207, 3221-3231. [CrossRef] [PubMed]

27. Lenaz, G. Mitochondria and reactive oxygen species. Which role in physiology and pathology? Adv. Exp. Med. Biol. 2012, 942, 93-136. [PubMed]

28. Brookes, P.S.; Yoon, Y.; Robotham, J.L.; Anders, M.W.; Sheu, S.S. Calcium, atp, and ROS: A mitochondrial love-hate triangle. Am. J. Physiol. Cell Physiol. 2004, 287, C817-C833. [CrossRef] [PubMed]

29. Chouchani, E.T.; Pell, V.R.; James, A.M.; Work, L.M.; Saeb-Parsy, K.; Frezza, C.; Krieg, T.; Murphy, M.P. A unifying mechanism for mitochondrial superoxide production during ischemia-reperfusion injury. Cell Metab. 2016, 23, 254-263. [CrossRef] [PubMed]

30. Genova, M.L.; Pich, M.M.; Bernacchia, A.; Bianchi, C.; Biondi, A.; Bovina, C.; Falasca, A.I.; Formiggini, G.; Castelli, G.P.; Lenaz, G. The mitochondrial production of reactive oxygen species in relation to aging and pathology. Ann. N. Y. Acad. Sci. 2004, 1011, 86-100. [CrossRef] [PubMed]

31. Griffiths, E.J.; Halestrap, A.P. Mitochondrial non-specific pores remain closed during cardiac ischaemia, but open upon reperfusion. Biochem. J. 1995, 307, 93-98. [CrossRef] [PubMed]

32. Li, P.; Nijhawan, D.; Budihardjo, I.; Srinivasula, S.M.; Ahmad, M.; Alnemri, E.S.; Wang, X. Cytochrome c and dATP-dependent formation of Apaf-1/caspase-9 complex initiates an apoptotic protease cascade. Cell 1997, 91, 479-489. [CrossRef]

33. Budihardjo, I.; Oliver, H.; Lutter, M.; Luo, X.; Wang, X. Biochemical pathways of caspase activation during apoptosis. Annu. Rev. Cell Dev. Biol. 1999, 15, 269-290. [CrossRef] [PubMed]

34. Wu, J.; Luo, X.; Yan, L.J. Two dimensional blue native/SDS-PAGE to identify mitochondrial complex I subunits modified by 4-hydroxynonenal (HNE). Front. Physiol. 2015, 6, 98. [CrossRef] [PubMed]

35. Yan, L.J. Analysis of oxidative modification of proteins. Curr. Protoc. Protein Sci. 2009. [CrossRef]

36. Anderson, E.J.; Katunga, L.A.; Willis, M.S. Mitochondria as a source and target of lipid peroxidation products in healthy and diseased heart. Clin. Exp. Pharmacol. Physiol. 2012, 39, 179-193. [CrossRef] [PubMed]

37. Ames, B.N.; Shigenaga, M.K. Oxidants are a major contributor to aging. Ann. N. Y. Acad. Sci. 1992, 663, 85-96. [CrossRef] [PubMed]

38. Shacter, E. Protein oxidative damage. Methods Enzymol. 2000, 319, 428-436. [PubMed] 
39. Chen, H.; Yoshioka, H.; Kim, G.S.; Jung, J.E.; Okami, N.; Sakata, H.; Maier, C.M.; Narasimhan, P.; Goeders, C.E.; Chan, P.H. Oxidative stress in ischemic brain damage: Mechanisms of cell death and potential molecular targets for neuroprotection. Antioxid. Redox Signal. 2011, 14, 1505-1517. [CrossRef] [PubMed]

40. Brookes, P.S.; Hoffman, D.L. Aging and cardiac ischemia-mitochondria and free radical consideration. In Oxidative Stress in Aging: From Model Systems to Human Diseases; Miwa, S., Bechkman, K.B., Muller, F.L., Eds.; Humana Press: Totowa, NJ, USA, 2008; pp. 253-268.

41. Lebuffe, G.; Schumacker, P.T.; Shao, Z.H.; Anderson, T.; Iwase, H.; Vanden Hoek, T.L. ROS and NO trigger early preconditioning: Relationship to mitochondrial KATP channel. Am. J. Physiol. Heart Circ. Physiol. 2003, 284, H299-H308. [CrossRef] [PubMed]

42. Wang, X.; Wang, H.; Xu, L.; Rozanski, D.J.; Sugawara, T.; Chan, P.H.; Trzaskos, J.M.; Feuerstein, G.Z. Significant neuroprotection against ischemic brain injury by inhibition of the MEK1 protein kinase in mice: Exploration of potential mechanism associated with apoptosis. J. Pharmacol. Exp. Ther. 2003, 304, 172-178. [CrossRef] [PubMed]

43. Liang, H.W.; Xia, Q.; Bruce, I.C. Reactive oxygen species mediate the neuroprotection conferred by a mitochondrial ATP-sensitive potassium channel opener during ischemia in the rat hippocampal slice. Brain Res. 2005, 1042, 169-175. [CrossRef] [PubMed]

44. Pong, K. Ischaemic preconditioning: Therapeutic implications for stroke? Expert Opin. Ther. Targets 2004, 8, 125-139. [CrossRef] [PubMed]

45. Blanco, M.; Lizasoain, I.; Sobrino, T.; Vivancos, J.; Castillo, J. Ischemic preconditioning: A novel target for neuroprotective therapy. Cerebrovasc. Dis. 2006, 21, 38-47. [CrossRef] [PubMed]

46. Kirino, T. Ischemic tolerance. J. Cereb. Blood Flow Metab. 2002, 22, 1283-1296. [CrossRef] [PubMed]

47. Zhao, $\mathrm{H}$. The protective effect of ischemic postconditioning against ischemic injury: From the heart to the brain. J. Neuroimmune Pharmacol. 2007, 2, 313-318. [CrossRef] [PubMed]

48. Thompson, J.W.; Dave, K.R.; Young, J.I.; Perez-Pinzon, M.A. Ischemic preconditioning alters the epigenetic profile of the brain from ischemic intolerance to ischemic tolerance. Neurotherapeutics 2013, 10, 789-797. [CrossRef] [PubMed]

49. N, T.V.; Sangwan, A.; Sharma, B.; Majid, A.; Gk, R. Cerebral ischemic preconditioning: The road so far. Mol. Neurobiol. 2015. [CrossRef] [PubMed]

50. Zhao, H.; Ren, C.; Chen, X.; Shen, J. From rapid to delayed and remote postconditioning: The evolving concept of ischemic postconditioning in brain ischemia. Curr. Drug Targets 2012, 13, 173-187. [CrossRef] [PubMed]

51. Stowe, A.M.; Wacker, B.K.; Cravens, P.D.; Perfater, J.L.; Li, M.K.; Hu, R.; Freie, A.B.; Stuve, O.; Gidday, J.M. CCL2 upregulation triggers hypoxic preconditioning-induced protection from stroke. J. Neuroinflamm. 2012, 9. [CrossRef] [PubMed]

52. Galle, A.A.; Jones, N.M. The neuroprotective actions of hypoxic preconditioning and postconditioning in a neonatal rat model of hypoxic-ischemic brain injury. Brain Res. 2013, 1498, 1-8. [CrossRef] [PubMed]

53. Stowe, A.M.; Altay, T.; Freie, A.B.; Gidday, J.M. Repetitive hypoxia extends endogenous neurovascular protection for stroke. Ann. Neurol. 2011, 69, 975-985. [CrossRef] [PubMed]

54. Riepe, M.W.; Ludolph, A.C. Chemical preconditioning: A cytoprotective strategy. Mol. Cell. Biochem. 1997, 174, 249-254. [CrossRef] [PubMed]

55. Hoshi, A.; Nakahara, T.; Kayama, H.; Yamamoto, T. Ischemic tolerance in chemical preconditioning: Possible role of astrocytic glutamine synthetase buffering glutamate-mediated neurotoxicity. J. Neurosci. Res. 2006, 84, 130-141. [CrossRef] [PubMed]

56. Riepe, M.W.; Esclaire, F.; Kasischke, K.; Schreiber, S.; Nakase, H.; Kempski, O.; Ludolph, A.C.; Dirnagl, U.; Hugon, J. Increased hypoxic tolerance by chemical inhibition of oxidative phosphorylation: "Chemical preconditioning". J. Cereb. Blood Flow Metab. 1997, 17, 257-264. [CrossRef] [PubMed]

57. Stetler, R.A.; Leak, R.K.; Gan, Y.; Li, P.; Zhang, F.; Hu, X.; Jing, Z.; Chen, J.; Zigmond, M.J.; Gao, Y. Preconditioning provides neuroprotection in models of CNS disease: Paradigms and clinical significance. Prog. Neurobiol. 2014, 114, 58-83. [CrossRef] [PubMed]

58. Jeong, J.I.; Lee, Y.W.; Kim, Y.K. Chemical hypoxia-induced cell death in human glioma cells: Role of reactive oxygen species, ATP depletion, mitochondrial damage and $\mathrm{Ca}^{2+}$. Neurochem. Res. 2003, 28, 1201-1211. [CrossRef] [PubMed] 
59. Roemgens, A.; Singh, S.; Beyer, C.; Arnold, S. Inducers of chemical hypoxia act in a gender- and brain region-specific manner on primary astrocyte viability and cytochrome c oxidase. Neurotox. Res. 2011, 20, 1-14. [CrossRef] [PubMed]

60. Danielisova, V.; Gottlieb, M.; Nemethova, M.; Kravcukova, P.; Domorakova, I.; Mechirova, E.; Burda, J. Bradykinin postconditioning protects pyramidal Ca1 neurons against delayed neuronal death in rat hippocampus. Cell. Mol. Neurobiol. 2009, 29, 871-878. [CrossRef] [PubMed]

61. Luo, X.; Li, R.; Yan, L.J. Roles of pyruvate, nadh, and mitochondrial complex I in redox balance and imbalance in $\beta$ cell function and dysfunction. J. Diabetes Res. 2015, 2015. [CrossRef] [PubMed]

62. Luo, X.; Wu, J.; Jing, S.; Yan, L.J. Hyperglycemic stress and carbon stress in diabetic glucotoxicity. Aging Dis. 2016, 7, 90-110. [CrossRef] [PubMed]

63. Lieberman, M.; Marks, A.D. Marks' Basic Medical Biochemistry: A Clinical Approach, 4th ed.; Wolters Kluwer/Lippincott Williams \& Wilkins: Philadelphia, PA, USA, 2013.

64. Sun, X.; Sun, J.; Liu, L.; Ding, Z. Isoflurane preconditioning and postconditioning in multiple organ protection. J. Biochem. Pharmacol. Res. 2013, 1, 6-14.

65. Hanley, P.J.; Ray, J.; Brandt, U.; Daut, J. Halothane, isoflurane and sevoflurane inhibit NADH: Ubiquinone oxidoreductase (complex I) of cardiac mitochondria. J. Physiol. 2002, 544, 687-693. [CrossRef] [PubMed]

66. Kayser, E.B.; Suthammarak, W.; Morgan, P.G.; Sedensky, M.M. Isoflurane selectively inhibits distal mitochondrial complex I in Caenorhabditis elegans. Anesth. Analg. 2011, 112, 1321-1329. [CrossRef] [PubMed]

67. Pravdic, D.; Hirata, N.; Barber, L.; Sedlic, F.; Bosnjak, Z.J.; Bienengraeber, M. Complex I and ATP synthase mediate membrane depolarization and matrix acidification by isoflurane in mitochondria. Eur. J. Pharmacol. 2012, 690, 149-157. [CrossRef] [PubMed]

68. Agarwal, B.; Dash, R.K.; Stowe, D.F.; Bosnjak, Z.J.; Camara, A.K. Isoflurane modulates cardiac mitochondrial bioenergetics by selectively attenuating respiratory complexes. Biochim. Biophys. Acta 2014, 1837, 354-365. [CrossRef] [PubMed]

69. Sosunov, S.A.; Ameer, X.; Niatsetskaya, Z.V.; Utkina-Sosunova, I.; Ratner, V.I.; Ten, V.S. Isoflurane anesthesia initiated at the onset of reperfusion attenuates oxidative and hypoxic-ischemic brain injury. PLoS ONE 2015, 10, e0120456. [CrossRef] [PubMed]

70. Schapira, A.H. Human complex I defects in neurodegenerative diseases. Biochim. Biophys. Acta 1998, 1364, 261-270. [CrossRef]

71. Lefort, N.; Glancy, B.; Bowen, B.; Willis, W.T.; Bailowitz, Z.; de Filippis, E.A.; Brophy, C.; Meyer, C.; Hojlund, K.; Yi, Z.; et al. Increased reactive oxygen species production and lower abundance of complex I subunits and carnitine palmitoyltransferase $1 \mathrm{~B}$ protein despite normal mitochondrial respiration in insulin-resistant human skeletal muscle. Diabetes 2010, 59, 2444-2452. [CrossRef] [PubMed]

72. St-Pierre, J.; Buckingham, J.A.; Roebuck, S.J.; Brand, M.D. Topology of superoxide production from different sites in the mitochondrial electron transport chain. J. Biol. Chem. 2002, 277, 44784-44790. [CrossRef] [PubMed]

73. Hirst, J.; King, M.S.; Pryde, K.R. The production of reactive oxygen species by complex i. Biochem. Soc. Trans. 2008, 36, 976-980. [CrossRef] [PubMed]

74. Ludwig, L.M.; Tanaka, K.; Eells, J.T.; Weihrauch, D.; Pagel, P.S.; Kersten, J.R.; Warltier, D.C. Preconditioning by isoflurane is mediated by reactive oxygen species generated from mitochondrial electron transport chain complex III. Anesth. Analg. 2004, 99, 1308-1315. [CrossRef] [PubMed]

75. Teixeira, G.; Chiari, P.; Fauconnier, J.; Abrial, M.; Couture-Lepetit, E.; Harisseh, R.; Pillot, B.; Lacampagne, A.; Tourneur, Y.; Gharib, A.; et al. Involvement of cyclophilin D and calcium in isoflurane-induced preconditioning. Anesthesiology 2015, 123, 1374-1384. [CrossRef] [PubMed]

76. Zhao, P.; Ji, G.; Xue, H.; Yu, W.; Zhao, X.; Ding, M.; Yang, Y.; Zuo, Z. Isoflurane postconditioning improved long-term neurological outcome possibly via inhibiting the mitochondrial permeability transition pore in neonatal rats after brain hypoxia-ischemia. Neuroscience 2014, 280, 193-203. [CrossRef] [PubMed]

77. Perier, C.; Bove, J.; Vila, M.; Przedborski, S. The rotenone model of parkinson's disease. Trends Neurosci. 2003, 26, 345-346. [CrossRef]

78. Schonfeld, P.; Reiser, G. Rotenone-like action of the branched-chain phytanic acid induces oxidative stress in mitochondria. J. Biol. Chem. 2006, 281, 7136-7142. [CrossRef] [PubMed] 
79. Marella, M.; Seo, B.B.; Nakamaru-Ogiso, E.; Greenamyre, J.T.; Matsuno-Yagi, A.; Yagi, T. Protection by the NDI1 gene against neurodegeneration in a rotenone rat model of parkinson's disease. PLOS ONE 2008, 3, e1433. [CrossRef] [PubMed]

80. Zhou, Q.; Liu, C.; Liu, W.; Zhang, H.; Zhang, R.; Liu, J.; Zhang, J.; Xu, C.; Liu, L.; Huang, S.; et al. Rotenone induction of hydrogen peroxide inhibits mTOR-mediated S6K1 and 4E-BP1/eIF4E pathways, leading to neuronal apoptosis. Toxicol. Sci. 2015, 143, 81-96. [CrossRef] [PubMed]

81. Yan, L.J.; Sumien, N.; Thangthaeng, N.; Forster, M.J. Reversible inactivation of dihydrolipoamide dehydrogenase by mitochondrial hydrogen peroxide. Free Radic. Res. 2013, 47, 123-133. [CrossRef] [PubMed]

82. Turrens, J.F.; Alexandre, A.; Lehninger, A.L. Ubisemiquinone is the electron donor for superoxide formation by complex III of heart mitochondria. Arch. Biochem. Biophys. 1985, 237, 408-414. [CrossRef]

83. Sun, F.; Huo, X.; Zhai, Y.; Wang, A.; Xu, J.; Su, D.; Bartlam, M.; Rao, Z. Crystal structure of mitochondrial respiratory membrane protein complex II. Cell 2005, 121, 1043-1057. [CrossRef] [PubMed]

84. Hirata, T.; Fukuse, T.; Ishikawa, S.; Hanaoka, S.; Chen, Q.; Shoji, T.; Wada, H. "Chemical preconditioning” by 3-nitropropionate reduces ischemia-reperfusion injury in cardiac-arrested rat lungs. Transplantation 2001, 71, 352-359. [CrossRef] [PubMed]

85. Brambrink, A.M.; Schneider, A.; Noga, H.; Astheimer, A.; Gotz, B.; Korner, I.; Heimann, A.; Welschof, M.; Kempski, O. Tolerance-inducing dose of 3-nitropropionic acid modulates bcl-2 and bax balance in the rat brain: A potential mechanism of chemical preconditioning. J. Cereb. Blood Flow Metab. 2000, 20, 1425-1436. [CrossRef] [PubMed]

86. Hoshi, A.; Nakahara, T.; Ogata, M.; Yamamoto, T. The critical threshold of 3-nitropropionic acid-induced ischemic tolerance in the rat. Brain Res. 2005, 1050, 33-39. [CrossRef] [PubMed]

87. Wiegand, F.; Liao, W.; Busch, C.; Castell, S.; Knapp, F.; Lindauer, U.; Megow, D.; Meisel, A.; Redetzky, A.; Ruscher, K.; et al. Respiratory chain inhibition induces tolerance to focal cerebral ischemia. J. Cereb. Blood Flow Metab. 1999, 19, 1229-1237. [CrossRef] [PubMed]

88. Cooper, C.E.; Brown, G.C. The inhibition of mitochondrial cytochrome oxidase by the gases carbon monoxide, nitric oxide, hydrogen cyanide and hydrogen sulfide: Chemical mechanism and physiological significance. J. Bioenerg. Biomembr. 2008, 40, 533-539. [CrossRef] [PubMed]

89. Correia, S.C.; Santos, R.X.; Cardoso, S.M.; Santos, M.S.; Oliveira, C.R.; Moreira, P.I. Cyanide preconditioning protects brain endothelial and NT2 neuron-like cells against glucotoxicity: Role of mitochondrial reactive oxygen species and HIF-1 $\alpha$. Neurobiol. Dis. 2012, 45, 206-218. [CrossRef] [PubMed]

90. Jensen, M.S.; Ahlemeyer, B.; Ravati, A.; Thakur, P.; Mennel, H.D.; Krieglstein, J. Preconditioning-induced protection against cyanide-induced neurotoxicity is mediated by preserving mitochondrial function. Neurochem. Int. 2002, 40, 285-293. [CrossRef]

91. Queiroga, C.S.; Almeida, A.S.; Martel, C.; Brenner, C.; Alves, P.M.; Vieira, H.L. Glutathionylation of adenine nucleotide translocase induced by carbon monoxide prevents mitochondrial membrane permeabilization and apoptosis. J. Biol. Chem. 2010, 285, 17077-17088. [CrossRef] [PubMed]

92. Hochgrafe, F.; Mostertz, J.; Albrecht, D.; Hecker, M. Fluorescence thiol modification assay: Oxidatively modified proteins in Bacillus subtilis. Mol. Microbiol. 2005, 58, 409-425. [CrossRef] [PubMed]

93. Lim, S.Y.; Davidson, S.M.; Hausenloy, D.J.; Yellon, D.M. Preconditioning and postconditioning: The essential role of the mitochondrial permeability transition pore. Cardiovasc. Res. 2007, 75, 530-535. [CrossRef] [PubMed]

94. Yan, L.J.; Christians, E.S.; Liu, L.; Xiao, X.; Sohal, R.S.; Benjamin, I.J. Mouse heat shock transcription factor 1 deficiency alters cardiac redox homeostasis and increases mitochondrial oxidative damage. EMBO J. 2002, 21, 5164-5172. [CrossRef] [PubMed]

95. Fan, Y.Y.; Shen, Z.; He, P.; Jiang, L.; Hou, W.W.; Shen, Y.; Zhang, X.N.; Hu, W.W.; Chen, Z. A novel neuroprotective strategy for ischemic stroke: Transient mild acidosis treatment by $\mathrm{CO}_{2}$ inhalation at reperfusion. J. Cereb. Blood Flow Metab. 2014, 34, 275-283. [CrossRef] [PubMed]

96. Garcia de Arriba, S.; Franke, H.; Pissarek, M.; Nieber, K.; Illes, P. Neuroprotection by ATP-dependent potassium channels in rat neocortical brain slices during hypoxia. Neurosci. Lett. 1999, 273, 13-16. [CrossRef]

97. Yamauchi, T.; Kashii, S.; Yasuyoshi, H.; Zhang, S.; Honda, Y.; Akaike, A. Mitochondrial ATP-sensitive potassium channel: A novel site for neuroprotection. Investig. Ophthalmol. Vis. Sci. 2003, 44, 2750-2756. [CrossRef] 
98. Kis, B.; Rajapakse, N.C.; Snipes, J.A.; Nagy, K.; Horiguchi, T.; Busija, D.W. Diazoxide induces delayed pre-conditioning in cultured rat cortical neurons. J. Neurochem. 2003, 87, 969-980. [CrossRef] [PubMed]

99. Robin, E.; Simerabet, M.; Hassoun, S.M.; Adamczyk, S.; Tavernier, B.; Vallet, B.; Bordet, R.; Lebuffe, G. Postconditioning in focal cerebral ischemia: Role of the mitochondrial ATP-dependent potassium channel. Brain Res. 2011, 1375, 137-146. [CrossRef] [PubMed]

100. O'Sullivan, J.C.; Yao, X.L.; Alam, H.; McCabe, J.T. Diazoxide, as a postconditioning and delayed preconditioning trigger, increases HSP25 and HSP70 in the central nervous system following combined cerebral stroke and hemorrhagic shock. J. Neurotrauma 2007, 24, 532-546. [CrossRef] [PubMed]

101. Wu, L.; Shen, F.; Lin, L.; Zhang, X.; Bruce, I.C.; Xia, Q. The neuroprotection conferred by activating the mitochondrial ATP-sensitive $\mathrm{K}^{+}$channel is mediated by inhibiting the mitochondrial permeability transition pore. Neurosci. Lett. 2006, 402, 184-189. [CrossRef] [PubMed]

102. Farkas, E.; Timmer, N.M.; Domoki, F.; Mihaly, A.; Luiten, P.G.; Bari, F. Post-ischemic administration of diazoxide attenuates long-term microglial activation in the rat brain after permanent carotid artery occlusion. Neurosci. Lett. 2005, 387, 168-172. [CrossRef] [PubMed]

103. Stetler, R.A.; Leak, R.K.; Yin, W.; Zhang, L.; Wang, S.; Gao, Y.; Chen, J. Mitochondrial biogenesis contributes to ischemic neuroprotection afforded by LPS pre-conditioning. J. Neurochem. 2012, 123, 125-137. [CrossRef] [PubMed]

104. Rosenzweig, H.L.; Minami, M.; Lessov, N.S.; Coste, S.C.; Stevens, S.L.; Henshall, D.C.; Meller, R.; Simon, R.P.; Stenzel-Poore, M.P. Endotoxin preconditioning protects against the cytotoxic effects of TNF $\alpha$ after stroke: A novel role for TNF $\alpha$ in LPS-ischemic tolerance. J. Cereb. Blood Flow Metab. 2007, 27, 1663-1674. [CrossRef] [PubMed]

105. Vartanian, K.B.; Stevens, S.L.; Marsh, B.J.; Williams-Karnesky, R.; Lessov, N.S.; Stenzel-Poore, M.P. LPS preconditioning redirects TLR signaling following stroke: TRIF-IRF3 plays a seminal role in mediating tolerance to ischemic injury. J. Neuroinflamm. 2011, 8. [CrossRef] [PubMed]

106. Marsh, B.; Stevens, S.L.; Packard, A.E.; Gopalan, B.; Hunter, B.; Leung, P.Y.; Harrington, C.A.; Stenzel-Poore, M.P. Systemic lipopolysaccharide protects the brain from ischemic injury by reprogramming the response of the brain to stroke: A critical role for IRF3. J. Neurosci. 2009, 29, 9839-9849. [CrossRef] [PubMed]

107. Li, W.C.; Jiang, R.; Jiang, D.M.; Zhu, F.C.; Su, B.; Qiao, B.; Qi, X.T. Lipopolysaccharide preconditioning attenuates apoptotic processes and improves neuropathologic changes after spinal cord injury in rats. Int. J. Neurosci. 2013. [CrossRef] [PubMed] 